Borneo Journal of Sciences and Technology, Volume (2), Issue (1), Pages: 07-12

DOI: https://doi.org/10.35370/bjost.2020.2.1-03

e-ISSN: 2672-7439

(C) 2018, UCTS Publisher.

Submitted: $14^{\text {th }}$ November $2019 \quad$ Accepted: $2^{\text {nd }}$ December $2019 \quad$ Published: $31^{\text {th }}$ January 2020

\title{
Factors Influencing the Price of Selected Building Materials in Northern Malaysia
}

\author{
${ }^{1}$ Ahmed Mohammed Kamaruddeen, ${ }^{2}$ Najihah Mohd Noor, ${ }^{1}$ Wahida Wahi \\ ${ }^{1}$ Quantity Surveying Programme, University College of Technology Sarawak \\ ${ }^{2}$ Department of Technology Management, Universiti Utara Malaysia
}

\begin{abstract}
Contractors usually obtain the current prices of building materials while tendering for construction projects. The reason is that the most current information about the prices of building materials is used to determine the most appropriate tender price. However, certain factors can be responsible for the changes in the prices of the building materials. This paper therefore aims to identify the factors influencing the prices of selected building materials in northern Malaysia. Forty copies of questionnaire were distributed to those selling building materials in northern Malaysia. Thirty copies of the questionnaire were completed and then returned. The data obtained were analyzed using the Statistical Package for Social Science (SPSS) version 20. The findings from this study suggest that the most influencing factors on the price of building materials are the cost of energy consumed in producing the building materials and the demand for the building materials. The findings from this research corroborate the existing body of knowledge on building materials in that cost of production and the level of demand play significant roles in determining the prices of building materials.
\end{abstract}

Keywords: Building Material, Price, Northern Malaysia

\section{INTRODUCTION}

The price of building materials changes when there is a change in any economic factors such as demand and supply. This is the reason why contractors are on the lookout for information on the current price of building materials during tendering for a construction project. The cost of building materials in modern construction generally accounts for approximately 60 percent of the total construction costs. Danso and Obeng-Ahenkora [1] state that fluctuations in the prices of construction materials have significant impact on the success of construction projects. These unforeseen price changes affect project execution rates and even have impact on the ability to finish the projects. This paper, therefore, seeks to identify the factors that mostly influence the price of building materials, and then compare the most influencing factors with the building materials in the northern region of Malaysia.

Despite the diverse literature on factors influencing cost in the construction industry, extensive literature search has shown that little attention has been directed towards the factors influencing the price of building materials in the Malaysian construction industry. Prior research has focused on the factors influencing the cost of building projects or housing. For example, Toh et al. [2] examined the critical cost factors of building construction projects in Malaysia. It was found that client requirements on quality are the most critical factor that influenced the costs of building construction projects. Bari et al. [3] also examined factors influencing the construction costs of the Industrialised Building System (IBS) projects in Malaysia. It was found that Project/IBS characteristics, contractor attributes, external market conditions were the leading factors that influenced the cost of Industrialised Building System projects in Malaysia while consultants and design parameters, external factors, and government/authority requirements were the least factors influencing the cost of IBS projects. Due to the aforementioned, this research seeks to identify the factors influencing the price of building materials in the northern region of Malaysia.

The research scope is restricted to the northern region because few states such as Kedah and Perlis share boundary with Thailand. It is envisaged that this boundary could influence economic activities that might have an impact on the price of building materials.

\section{LITERATURE REVIEW}

The Construction Industry Development Board (CIDB) Malaysia defines the price of building material as the transaction cost between contractors and the suppliers under the normal specified credit terms with a view to giving discount to an average contractor. The size of

Corresponding Author: Wahida Wahi. Quantity Surveying Programme, University College of Technology Sarawak, wahidawahi@ucts.edu.my. 


\section{Factors Influencing the Price of Selected Building Materials in Northern Malaysia}

such purchase shall normally be in bulk, taking into consideration the normal discount given to its clients, by including all applicable taxes payable to the government and the transportation costs within practicable distances as well as profit.

\section{The Trends in the Price of Building Materials}

The price of building materials varies from time to time depending on the factors that are affecting it. In 2014, construction material costs rose slightly. Cement price increased by 3 percent compared to 2013. While common bricks price was slightly up in 2014 , the price of common bricks declined steadily for the past several years. The price fluctuated due to the demand of the global market.

On the other hand, after six years of flat prices, the price of limestone rose from 2 to 3 percent in 2013. In 2014, limestone prices flattened again and remained stable compared to the other types of building materials. Cement and concrete products increased by about 1 percent in 2014. This may have occurred due to a slowdown in public projects that used a large amount of concrete.

The price of paint has been stable and may have been flattened out due to a considerable increase from 6 to 8 percent. The price was moderated after the increase in the demand for the last two years in the market. While the price of stainless steel continued to slide down in 2014 after the high price in 2011 and 2012, the prices declined at 40 percent and 12 percent in 2018.

The price of building material depends on many factors. Some of the factors that can affect the price of building materials are importation, monetary policy, inflation rate, global demand, transportation, exchange rate, interest rate and energy cost $[1,4,5]$.

Identifying factors affecting the price of building materials will help in determining the causes of the fluctuation in the price of building materials. This study intends to focus on five types of building materials, such as cement, reinforcement bar, paint, timber, and stone, with a view to identifying the factors affecting their prices.

\section{Macroeconomic Policy}

In the economy, recession can be defined as the contraction in business activities. It is a general slowdown in all macroeconomic indicators such as GDP (Gross Domestic Product), investment spending, capacity utilization, household income, business profits, and inflation, which usually lead to bankruptcies and the rise of unemployment. During the recession, there will be a slowdown in demand for goods and services. As a result of the slowdown in demand, the price of building material will be reduced than it should be, thus preventing the contractors from involving in the construction of many projects. This situation will result in reducing the demand for the building materials and subsequently affect the prices of building materials [5].

\section{Demand}

Price of building materials can also be affected by global demand. The prices of the materials become higher than necessary because it is inevitable for the industry to use some of the materials that are in the higher demand. Despite the high cost, the industry will still use it to complete the project. So, the increase in the demand for the material will lead to an increase in the price of the building materials. Zhou and Zhao [5] state that the prices of building materials such as cement would respond to the market situation by the economic law of supply and demand.

\section{Energy Cost}

An increase in the cost of energy source such as fuel can have a significant impact on the construction industry. For example, the cost of energy like fuel will determine the price of the building materials. If the cost of fuel is high, the cost of building materials will increase because it will have a direct effect on the shipping cost of all the building materials. Energy cost constitutes a significant percentage of the total price of any building material [6].

\section{Monetary Policy}

Monetary policy is being used for assessing the supply of money and interest rates to achieve the objectives of the desired economic policy. If the economy is in recession, the government would aim at boosting economic activity through expansionary monetary policy by reducing interest rates, thereby leading to the increase in the supply of money. Adversely, if there is a need for a reduction in economic activity, due to rate of inflation, the government would put deflationary monetary policy in operation so as to increase interest rates and reduce the rate of growth in the money supply $[4,7]$.

\section{Inflation Rate}

Inflation can be defined as a sustained increase in the general price level of goods and services in an economy over some time. Inflation reflects the reduction of the purchasing power per unit of money. As the raw materials increase in price, the building materials will, 
in turn, become costly and similarly, the corresponding services will become expensive. Thus, inflation will cause the price of building materials to move upward [8].

\section{Interest Rate}

Interest rate is the cost of borrowing money. If the interest rates increase, borrowing money will become more expensive, thereby dampening consumers' demand for mortgages and other loan products. This situation will have an impact on real estate prices. The increase in interest rates can also lead to an increase in default rates, as holders of adjustable-rate debt find themselves faced with higher payments. There are strong relationships between exchange rate, inflation rate and interest rate as regards the prices of building materials [8].

\section{Currency Exchange Rate}

Exchange rate plays an important role in firms that export goods and import raw materials. Essentially, a depreciation or devaluation will make exports cheaper. The exporting firms will obtain benefits while an appreciation will make the exports become expensive and will eventually reduce the competitiveness of the exporting firms. Agene [9] states that the changes in the country's import and export will affect the exchange rate. The price of building materials will fluctuate according to the exchange rate of a country [4].

\section{Importation}

Oladipo and Oni [8] state that about 50 percent of the building materials and components that are being used in construction are sourced from overseas. The cost of importing the building materials from overseas is higher than that of the local materials. This can increase the total cost of construction. According to Uwah [10], the high cost in construction materials has become a major concern to the present-day construction industry.

\section{Transportation}

The increase in fuel cost has a significant effect on trends, the price of oil-based material and increases the transportation cost of the building materials to the project site. Due to the increased cost of transportation, the cost of building materials is also increased. As stated by Danso and Obeng-Ahenkora [1], transportation cost is one of the factors that affect the price of cement in India.

\section{METHOD}

This research adopted a quantitative approach, using questionnaire as an instrument for data collection. The factors influencing the price of building materials were obtained from related literature and were presented in the questionnaire. A simple random sampling approach was adopted to select respondents. Business shops where building materials are sold were surveyed using a self-administered questionnaire. Data were coded and analyzed using Statistical Package for Social Science (SPSS) to run descriptive statistics, correlation, and regression analyses. Business shops selling building materials were identified across major towns in Kedah State and were personally given copies of the questionnaire after explaining the purpose of the research. The respondents were asked when the completed copies of the questionnaire can be collected by the researcher. The completed copies of the questionnaire were collected on the date indicated by respondents. A total of 40 copies of the questionnaire were distributed and 30 copies were completed and returned yielding a $75 \%$ response rate.

\section{RESULTS}

Table 1: Demographic profile of respondents

\begin{tabular}{|c|c|c|}
\hline Gender & Frequency & Percentage \\
\hline Male & 26 & 86.7 \\
\hline Female & 4 & 13.3 \\
\hline \multicolumn{3}{|l|}{ Age } \\
\hline Less than 20 & 0 & 0 \\
\hline $21-30$ & 6 & 20 \\
\hline $31-40$ & 7 & 23.3 \\
\hline $41-50$ & 12 & 40 \\
\hline Above 50 years & 5 & 16.7 \\
\hline \multicolumn{3}{|l|}{ Race } \\
\hline Malay & 8 & 26.7 \\
\hline Chinese & 20 & 66.7 \\
\hline Indian & 2 & 6.6 \\
\hline \multicolumn{3}{|l|}{ Level of education } \\
\hline SPM & 10 & 33.3 \\
\hline Certificate & 5 & 16.7 \\
\hline STPM & 2 & 6.7 \\
\hline Matriculation & 1 & 3.3 \\
\hline Diploma & 3 & 10.0 \\
\hline Degree & 3 & 10.0 \\
\hline Others & 6 & 20.0 \\
\hline \multicolumn{3}{|l|}{ Work experience } \\
\hline Below 6 years & 5 & 16.7 \\
\hline $6-10$ years & 3 & 10 \\
\hline $11-15$ years & 16 & 53.3 \\
\hline More than 15 years & 6 & 20.0 \\
\hline
\end{tabular}


Factors Influencing the Price of Selected Building Materials in Northern Malaysia

\begin{tabular}{|l|c|c|}
\hline Position & & \\
\hline Business owner & 22 & 73.3 \\
\hline Employee & 6 & 20.0 \\
\hline Others & 2 & 6.7 \\
\hline
\end{tabular}

Table 1 presents the demographic profile of the respondents. It shows that male respondents $(86.7 \%)$ were more than female respondents $(26.7 \%)$. So, the total number of the respondents was thirty $(\mathrm{N}=30)$ totaling $100.0 \%$. As regards age group, the highest percentage was between 41 and 50 years old $(40 \%)$, followed by 31 to 40 years old (23.3\%), and then 21 to 30 years old $(20 \%)$. The least percentage $(16.7 \%)$ consisted of people who were more than 50 years old. The respondents consisted of three groups. The Chinese had the highest percentage (66.7\%), followed by Malay $(26.7 \%)$ and then the last group consisted of Indians $(6.6 \%)$. As regards the level of education, $33.3 \%$ had SPM, 20\% had SPM, 16.7\% had certificate while respondents who had a diploma and bachelor's degrees were 10.\% each. Also, 6.7\% had STPM and a respondent had matriculation (3.3\%). Regarding the respondents' work experience, the highest percentage was between 11 and 15 years $(53.3 \%)$. Next was a group of respondents with more than 15 years of experience $(20 \%)$. The next group was respondents with below 6 years of work experience (16.7\%) while the lowest group consisted of respondents with between 6 and 10 years of work experience(10\%). Regarding the position, the highest group of respondents were business owners $(73.3 \%)$, followed by respondents that were employees $(20 \%)$ and the last group belong to others $(6.7 \%)$.

Table 2: Ranking of the factors influencing the price of cement

\begin{tabular}{clccc}
\hline Rank & $\begin{array}{l}\text { Variables/ } \\
\text { Dimension }\end{array}$ & Mean & SD & Level \\
\hline $\mathbf{1}$ & Demand & 4.63 & 0.57 & High \\
$\mathbf{2}$ & Energy cost & 4.10 & 0.76 & High \\
$\mathbf{3}$ & Exchange rate & 3.70 & 0.88 & Moderate \\
$\mathbf{4}$ & Importation & 3.63 & 0.95 & Moderate \\
$\mathbf{5}$ & Interest rate & 3.66 & 0.92 & Moderate \\
$\mathbf{6}$ & Transportation & 3.60 & 0.81 & Moderate \\
$\mathbf{7}$ & Inflation rate & 3.33 & 1.00 & Moderate \\
$\mathbf{8}$ & Monetary & 3.30 & 1.23 & Moderate \\
& $\begin{array}{l}\text { policy } \\
\text { Overall } \\
\text { Factors }\end{array}$ & $\mathbf{3 . 7 4}$ & $\mathbf{0 . 8 9}$ & Moderate \\
\hline
\end{tabular}

Table 3: Ranking of the factors influencing the price of stone

\begin{tabular}{ccccc}
\hline Rank & Variables & Mean & SD & Level \\
\hline $\mathbf{1}$ & Energy cost & 4.53 & 0.61 & High \\
\hline
\end{tabular}

\begin{tabular}{lllll}
\hline $\mathbf{2}$ & Demand & 4.30 & 0.69 & High \\
$\mathbf{3}$ & Transportation & 4.13 & 0.89 & High \\
$\mathbf{4}$ & Importation & 4.00 & 0.86 & High \\
$\mathbf{5}$ & Interest rate & 3.46 & 0.87 & Moderate \\
$\mathbf{6}$ & Inflation rate & 3.36 & 0.80 & Moderate \\
$\mathbf{7}$ & Exchange rate & 3.33 & 0.65 & Moderate \\
$\mathbf{8}$ & Monetary & 3.13 & 0.80 & Moderate \\
& $\begin{array}{l}\text { policy } \\
\text { Overall }\end{array}$ & $\mathbf{3 . 7 8}$ & $\mathbf{0 . 7 7}$ & High \\
& Factors & & & \\
\hline
\end{tabular}

Table 4: Ranking of the factors influencing the price of iron bar

\begin{tabular}{clccc}
\hline Rank & Variables & Mean & SD & Level \\
\hline $\mathbf{1}$ & Energy cost & 4.70 & 0.54 & High \\
$\mathbf{2}$ & Demand & 4.56 & 0.61 & High \\
$\mathbf{3}$ & Transportation & 4.13 & 0.67 & High \\
$\mathbf{4}$ & Inflation rate & 4.16 & 0.80 & High \\
$\mathbf{5}$ & Importation & 3.83 & 0.86 & High \\
$\mathbf{6}$ & Interest rate & 3.40 & 0.76 & Moderate \\
$\mathbf{7}$ & Exchange rate & 3.33 & 0.75 & Moderate \\
$\mathbf{8}$ & Monetary policy & 3.26 & 0.73 & Moderate \\
& Overall Factors & $\mathbf{3 . 9 2}$ & $\mathbf{0 . 7 1}$ & High \\
\hline
\end{tabular}

Table 5: Ranking of the factors influencing the price of timber

\begin{tabular}{clccc}
\hline Rank & Variables & Mean & SD & Level \\
\hline $\mathbf{1}$ & Demand & 4.46 & 0.66 & High \\
$\mathbf{2}$ & Energy cost & 4.23 & 0.61 & High \\
$\mathbf{3}$ & Transportation & 4.10 & 0.69 & High \\
$\mathbf{4}$ & Importation & 3.93 & 0.83 & High \\
$\mathbf{5}$ & Inflation rate & 3.20 & 0.71 & Moderate \\
$\mathbf{6}$ & Interest rate & 3.13 & 0.70 & Moderate \\
$\mathbf{7}$ & Exchange rate & 3.10 & 0.63 & Moderate \\
$\mathbf{8}$ & Monetary policy & 3.23 & 0.72 & Moderate \\
& Overall Factors & $\mathbf{3 . 6 7}$ & $\mathbf{0 . 6 9}$ & Moderate \\
\hline
\end{tabular}




\section{Factors Influencing the Price of Selected Building Materials in Northern Malaysia}

Table 6: Ranking of the factors influencing the price of paint

\begin{tabular}{clccc}
\hline Rank & Variables & Mean & SD & Level \\
\hline $\mathbf{1}$ & Demand & 4.46 & 0.65 & High \\
$\mathbf{2}$ & Energy cost & 4.36 & 0.71 & High \\
$\mathbf{3}$ & Transportation & 4.20 & 0.71 & High \\
$\mathbf{4}$ & Importation & 4.16 & 0.77 & High \\
$\mathbf{5}$ & Monetary & 3.43 & 0.82 & Moderate \\
& policy & & & \\
$\mathbf{6}$ & Interest rate & 3.36 & 0.93 & Moderate \\
$\mathbf{7}$ & Exchange rate & 3.30 & 0.83 & Moderate \\
$\mathbf{8}$ & Inflation rate & 3.13 & 0.76 & Moderate \\
& Overall & $\mathbf{3 . 8 0}$ & $\mathbf{0 . 7 7}$ & High \\
& Factors & & & \\
\hline
\end{tabular}

The following eight (8) factors were identified to be influencing the price of building materials in northern Malaysia: transportation, exchange rate, monetary policy, importation, interest rate, inflation rate, demand and cost of energy.

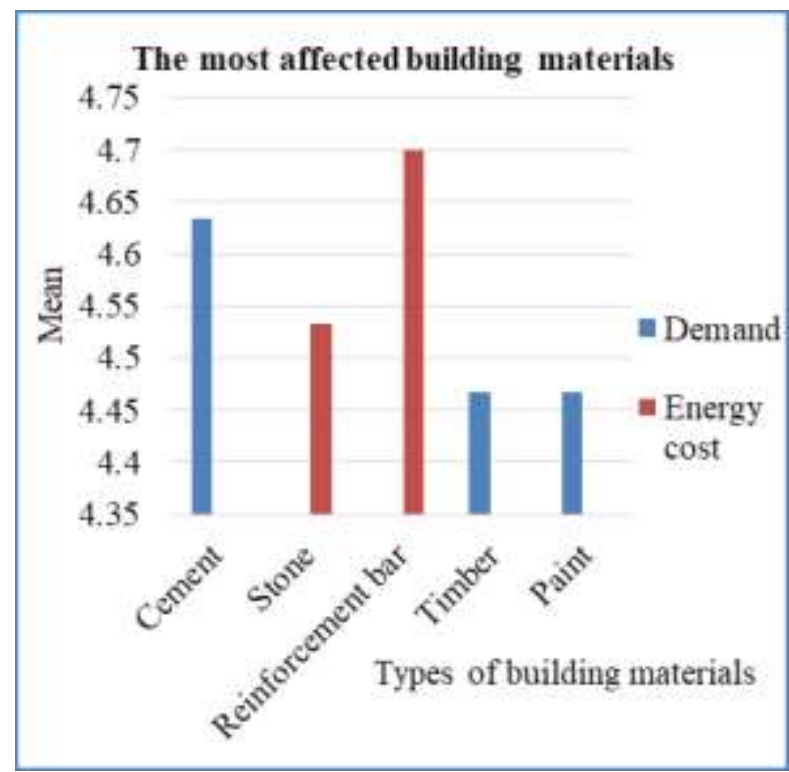

Figure 1: The mostly affected building materials by the factors.

Figure 1 shows a comparison of the most influencing factors affecting the price of the building materials. The types of building materials are cement, stone, reinforcement bar, timber, and paint.

The most influencing factors of these five types of building materials were the energy cost and the demand for the material. For cement, timber, and paint, the most influencing factor was energy cost while the most influencing factor of stone and timber was the demand for the material.

\section{DISCUSSION}

The descriptive statistics showed a high mean score for two factors influencing the price of various building materials, namely, demand and cost of energy. For cement, the high level of significance was the demand factor $($ mean $=4.63$, standard deviation $=0.57)$. The high level of significance for stone was the energy cost factor (mean $=4.53$, standard deviation $=0.61$ ). For the reinforcement bar, the high level of significance was the energy cost factor (mean $=4.70$, standard deviation $=0.54$ ). While the high level of significance for timber was the demand factor (mean $=4.46$, standard deviation $=0.66$ ), the significance level for paint was also the demand factor (mean $=4.46$, standard deviation $=0.65$ ).

The descriptive analysis of the research therefore suggests that the most influencing factors among the building material are demand and energy cost. For cement, timber, and paint, the most influencing factor of the price is demand. Also, for reinforcement bars and stone the most influencing factor is energy cost.

Concerning demand, the finding of this study has shown that demand has an impact on the price of building materials like cement, timber, and paint. The result suggests that the demand for building materials plays a very significant role in determining their prices. This finding is consistent with an earlier study conducted by Oladipo and Oni [8], who found that the price of building materials like cement responded to the market situation by an economic law of supply and demand. That is to say, the increase in the demand for the building materials increases the price of the materials. This situation therefore leads to a high construction cost for completing a project since the use of the building materials is unavoidable.

Concerning energy cost, the finding from this study also suggests that energy cost has a significant influence on the price of building materials. In other words, energy cost is another significant factor that plays a crucial role in determining the prices of reinforcement bar and stone. This result is consistent with an earlier study by Braden [7] who stated that, even if the supply and demand are stable, there is high possibility for the building material prices to increase whenever there is an increase in the price of the fuel which will be consumed by the vehicles that transport the materials. Therefore, the increase in the cost of fuel would certainly lead to an increase in the price of the building materials.

\section{CONCLUSION}

The objective of this study was to identify the factors influencing the price of building materials in the northern region of Malaysia. Future research can cover 
other regions of Malaysia. The types of building materials that have been examined in this paper are only five, namely, cement, timber, paint, reinforcement bar and stone only. The ranking of the factors influencing the price of building materials based on the mean score is a major limitation to this research. Future research can examine other types of building materials. The relatively small sample size may be considered a major limitation of this research. Though this research used a cross-sectional approach in collecting data, future research should consider a longitudinal approach and the Relative Impotence Index (RII) values to rank the factors.

\section{REFERENCES}

[1] Danso, H. and Obeng-Ahenkora, N.K. (2018). Major Determinants of Prices Increase of Building Materials on Ghanaian Construction Market. Open Journal of Civil Engineering, 8, 142-154.

[2] Toh, T. C., Ting, C., Ali, K. N., Aliagha, G. U., Munira O. (2012). Critical cost factors of building construction projects in Malaysia. Procedia Social and Behavioral Sciences 57, 360 - 367.

[3] Bari, N. A. A., Ismail, R. Y. N., Jaapar, N. and Ahmad, N. (2012). Factors Influencing the Construction Cost of Industrialised Building
System (IBS) Projects. Procedia - Social and Behavioral Sciences 35, 689 - 696.

[4] Akanni, P., Oke, A. and Omotilewa, O. (2014). Implications of Rising Cost of Building Materials in Lagos State Nigeria. SAGE Open, 4, 1-7.

[5] Zhou H. and Zhao J. H. (2013). Analysis of Factors to Cause the Price Change of Building Materials. Advanced Materials Research Vol. 683, 668-671.

[6] Windapo, A. and Cattell, K. (2012). Examining the Trends in Building Material Prices: Built Environment Stakeholders' Perspectives. Management of Construction. Research to Practice, 1, 187-201.

[7] Braden, C. (2009). Construction material cost: Recent years and beyond. Cost engineering. 5(1), 17-21.

[8] Oladipo, F.O. and Oni, O. J. (2012). A Review of Selected Macroeconomic Factors Impacting Building Material Prices In Developing Countries - A Case of Nigeria, Ethiopian Journal of Environmental Studies and Management EJESM Vol. 5 No. 2, 131-137.

[9] Agene, C. E. (1991). Foreign Exchange International Trade in Nigeria. Gene Publications Ltd. Lagos.

[10] Uwah, J. (1995). Making Cement Affordable, Business Times Sept. 18, 16. 